\title{
Luottamusmieskoulutuksen uudet haasteet
}

TVK-laisessa Postivirkamiesliitossa - kuten varmaan muissakin ammattiliitoissa - on uudistettu työpaikoilla toimivien luottamusmiesten peruskoulutusta.

Paineet koulutuksen uudistamiseen ovat syntyneet $\mathrm{mm}$. luottamusmiehen aseman ja tehtävien muuttumisen vuoksi. Luottamusmies ei ole enää pelkkä sopimusten tulkitsija ja erimielisyyksien sovittelija, vaan hän on yhä enemmän mukana työntekoon liittyvässä päätöksenteossa. Käsitteet yhteistoiminta, virastodemokratia, rationalisointi, työn henkinen kuormitus, työntutkimus, työn organisointi jne. ovat tulleet tutuiksi tämän päivän luottamusmiehelle.

Luottamusmiehellä pitää olla laajoja henkisiä resursseja venyä monelle suunnalle. Vaatimukset ovat kasvaneet: työnantajapuolella on omat erikoismiehensä joka lähtöön. Usein vielä työnantajapuolen edustajilla on takanaan korkeampi koulutuksellinen pätevyys kuin luottamusmiehellä. Tietysti luottamusmiehellä on kokemuksen ja järjestökoulutuksen kautta saatua pätevyyttä, jota vastapuolella saattaa olla vähemmän.

Näyttää kuitenkin siltä, että se aika, jolloin luottamusmies oli tiedollisesti niskan päällä, alkaa olla ohi.

\section{Ajatusmalli luottamusmies- toiminnasta}

Uudistuksen eräs alkupiste oli syksyllä 1983 TVK-laisille kouluttajille pidetty Didaktiikka I seminaari. Siellä pohdittiin Yrjö Engeströmin johdolla, mitä on hyvä opettaminen ja oppiminen. Samalla tehtiin ryhmätyönä ajatusmalleja luottamusmiesten peruskurssille. Tavoitteena oli kehittää ajatusmalli, joka olisi mahdollisimman korkealla yleistystasolla niin että sen avulla luottamusmiehet voisivat toimia kaikissa eteentulevissa tilanteissa.

Ryhmä, jossa olin mukana sai aikaan mallin, joka kuvaa ay-toimintaa 1980-1990-luvuilla. Sen perusoivallus on, että luottamustoiminta on osa ammattiyhdistysliikkeen toimintaa eikä pelkästään osa sopimusjärjestelmää.

Ajatusmalli lähtee liikkeelle jokapäiväisestä työprosessista. Ammattiyhdistysliike toimii työn sisällä: pyrkii järjestöjen toiminnan avulla vaikuttamaan työntekijöiden oikeuksiin ja velvollisuuksiin sekä työn sisältöön ja työympäristöön. Luottamusmiesjärjestelmä on yksi vaikuttamisjärjestelmä. Muita vaikuttamisjärjestelmiä ovat mm. työsuojelun yhteistoiminta ja virastodemokratia/yhteistoimintamenettely. Ammattiyhdistysliikkeen toiminnan keski- 
pisteenä on jäsen. Koko toiminta tähtää jäsenen, ihmisen parhaaksi.

Työkäsitteen ympärillä on yhteiskunta: se on jäsenen elinympäristö. Siellä on hänen kotinsa, perheensä ja työn ulkopuolinen elämänsä. Jäsenellä on myös omat käsityksensä elämän arvoista ja sen mukaiset asenteet työhön, ammattiyhdistystoimintaan ja elämiseen. Nämä asenteet vaikuttavat myös ay-toimintaan ja luottamusmiestoimintaan.

Ammattiyhdistysliike pyrkii toiminnallaan vaikuttamaan jäsenen asemaan ja hyvinvointiin myös työn ulkopuolella, yhteiskunnassa. Toisaalta yhteiskunnallinen tilanne ja yhteiskunnalliset tekijät vaikuttavat sekä työhön että ay-liikkeen toimintaan.

Ammattiyhdistysliikkeen toiminta ja vaikutussuunnat voidaan pelkistää kahdeksi akseliksi: työn sisältö - työympäristö ja työntekijän oikeudet - velvollisuudet. Nämä vaikutussuunnat ulottuvat työpaikalta yhteiskuntaan ja yksityiselämään saakka.

\section{Opetussuunnitelma}

Ajatusmallin lisäksi luottamusmiesten peruskurssista on tehty kaksiosainen opetussuunnitelma. Toinen osa on ns. yleinen osa, joka kertoo kurssin "hallinnolliset" asiat: tavoitteet, yhteydet muuhun koulutukseen, yleisjärjestelyt ja opetusjärjestelyt. Kurssin yhdeksi tavoitteeksi aśetettiin kokonaiskuvan hahmottaminen ammattiyhdistysliikkeen ja luottamusmiehen toiminnasta työelämässä sekä yhteiskunnassa: miten ay-liike pyrkii mm. luottamusmiestoiminnan avulla vaikuttamaan työn sisäisiin ja ulkoisiin tekijöihin sekä työntekijöiden palvelussuhteen ehtoihin. Toisena tavoitteena on antaa luottamusmiehille valmiuksia osallistua päätöksenteon valmisteluihin ja päätöksentekoon työpaikkatasolla yhteistyössä työnantajan edustajien ja ammattiosaston kanssa. Kolmantena tavoitteena on myönteisen minäkuvan ja hyvän itsetunnon kehittäminen.

Opetussuunnitelman ns. erityinen osa käsittää aihekohtaiset opetussuunnitelmat eli miten kukin opetustunti toteutetaan. Opettajien sivutoimisuudesta ja persoonallisista opetustottumuksista johtuen tämä osa opetuksen suunnittelusta on osoittautunut vaikeaksi.

Kurssikutsun mukana osanottajille on lähetetty ennakkotehtävä. Siinä pyydetään osanottajia havainnoimaan omaa työympäristöäär ja siellä esiintyviä ristiriitoja sekä ay-toiminnan nykytilaa. Tällä pyritään suuntaamaan osanot- tajien ajattelua kurssin keskeisiin, asioihin. Käytännössä ennakkotehtävä on toiminut: ristiriitoja on löytynyt runsaasti ja ne ovat toimineet koko viikon ajan lähtökohtana opetukselle ja keskusteluille. Ne ovat myös osoittaneet eri puolilta Suomea tulleille osanottajille, miten erilaisia ongelmia on olemassa ja toisaalta mitkä kysymykset ovat samantapaisina esillä eri puolilla maata.

\section{Kehittämistarpeita}

Viiden kurssin antamien kokemusten perusteella voi todeta, että vaikka luottamusmiesten peruskurssi onkin paljon parempi kuin edelliset versiot, se on vieläkin ajatuksellisesti ja teknisesti keskeneräinen. Tuskin sitä saadaan koskaan täysin valmiiksi, sillä tilanne työpaikoilla muuttuu jatkuvasti. Selviä puutteita ovat kuitenkin tuntikohtaisten opetussuunnitelmien puuttuminen sekä seurantajärjestelmä, joka kertoisi, miten koulutus vaikuttaa luottamusmiestoimintaan.

Suurin muutospaine kohdistuu kurssin pituuteen. Viikkokurssi on aivan liian lyhyt sen laaja-alaisen pätevyyden syntymiseksi, jota luottamusmies tarvitsee. Näyttääkin siltä, että perinteisen viikkokurssiajattelun sijasta olisi lähdettävä ennakkoluulottomasti pohtimaan uutta koulutusmuotoa. Sen tulisi olla ajallisesti pitempi, jossa koulutus ja luottamusmiehen toiminta vuorottelisivat mielekkäässä tahdissa.

Toinen nykyisen viikkokurssin perusongelma on, että oppimisprosessi "katkeaa" kurssin päättyessä. Sen jälkeen ei ole olemassa järjestelmää, joka tuottaisi tietoa siitä, miten kurssin aikana tapahtunut oppiminen toimii käytännössä ja minkä laatuista oppiminen on ollut. Kurssiarvioinnit - ainakin perinteisessä lomakemuodossa - mittaavat oppimistuloksia vain luokkahuoneessa. Ne eivät kerro sitä, miten luottamusmies on saamansa koulutuksen avulla pystynyt ratkaisemaan eri ongelmia ja kehittämään toimintaansa.

Yksi pohtimisen arvoinen alue on koulutuksen sisältö. Onko se vain nykytilaan sopeuttavaa vai antaako se välineitä vaikuttaa esimerkiksi tuleviin muutoksiin jo ennakolta? Joka tapauksessa koulutuksen tulisi antaa luottamusmiehille valmiuksia vaikuttaa työprosesseihin ja työn sisällön kehittämiseen. Tämä on tärkeä seikka jo senkin vuoksi, että työn sisällöstä ja työprosessista löytyvät monien luottamusmiehen käsiteltäväksi tulevien ongelmien syyt. Oman kiihdytyksensä tilanteeseen tuo tekninen kehitys, jonka ansiosta työntutki- 
mus, tulosvastuullisuus, tulosten seuranta jne. kehittyvät huimaa vauhtia.

Nykyiset säädökset ja sopimukset erottavat luottamusmiestoiminnan ja työsuojelutoiminnan toisistaan. Koulutuksen osallistumista säätelevä koulutussopimus tekee samoin. Todellisuus työpaikoilla on kuitenkin toisenlainen: ongelma tai ristiriita on yleensä moni-ilmeinen, ja se on yhtä sekä luottamusmieskysymys että työsuojelukysymys. Eli luottamusmiehiltä ja työsuojeluvaltuutetuilta vaaditaan tietoa ja yhteistyökykyä yli oman tehtäväalueensa. Herää kysymys: opetammeko me heille yhteistyötaitoa ja yhteistä tietoa vai opetammeko erillisiä tietoja?

\section{Haasteita}

Luottamusmiesten koulutuksen kehittäminen on yksi osa koko ay-toiminnan kehittämisvaatimusta: miten ammattijärjestöt pystyvät vastaamaan työelämän muutoksista aiheutuviin uusiin haasteisiin. Toinen koulutuksen suunnitteluun ja tavoiteasetteluun liittyvä kysymys on se, mikä on ammattijärjestöjen osuus ja vastuu työelämän kehitysprosessissa?

Tätä sietäisi pohtia - varsinkin kun yhteistoimintajärjestelmien kehittymisen myötä luottamusmiehet ja järjestöt ovat sitoutumassa yhä enemmän työelämässä tapahtuvaan päätöksentekoon. 